\title{
Opinion \\ Birds and the Convention on Biological Diversity: can ornithologists and bird conservationists make a difference?
}

PETER HERKENRATH

\begin{abstract}
Summary
Upon its adoption in 1992, the Convention on Biological Diversity (CBD) was greeted with enthusiasm by the conservation community including bird conservationists. Nine years after its entry into force in 1993, the CBD still has to live up to the original high expectations if it is to halt, or even slow, the loss of biodiversity at the ecosystem, species and genetic level. Among the reasons for this shortcoming, the rather vague nature of obligations for the 182 governments who have ratified the Convention is probably the most important. National Biodiversity Strategies and Action Plans (NBSAPs) form the most significant instrument for the implementation of the CBD. The Global Environment Facility (GEF) is supporting the NBSAPs financially, as well as local, national and regional projects, many of which are relevant for bird conservation. Being the best-researched animal taxa, birds could serve relatively easily as indicators for the success of efforts under the Convention. Some cases, where ornithological data are being used within NBSAPs and related processes, are highlighted. From the early stages of planning, bird surveyors should take the potential use of their results by decision-makers into account. For ensuring that survey data are fed into NBSAPs and other similar policy documents, a strong collaboration of ornithologists and birdwatchers with non-governmental conservation organizations is recommended.
\end{abstract}

\section{Introduction}

The Convention on Biological Diversity (CBD) was adopted on 22 May 1992 in Kenya and opened for signature at the United Nations Conference on Environment and Development, the so-called 'Earth Summit', in Rio de Janeiro in June 1992. The Convention was greeted with enthusiasm by conservationists, including those involved in bird conservation. Collar et al. (1994) noted: 'At the 1992 Earth Summit in Rio de Janeiro biological diversity rose from its humble origins in the recondite vocabulary of tropical ecologists to become a new influence in the social, economic and political thinking of late twentieth century man. The coming into force of the Convention on Biological Diversity, on 29 December 1993, was perhaps final confirmation that the conservation of nature has attained an appropriate level on the global agenda of the community of nations'. The CBD was regarded as 'a true conceptual, practical and political breakthrough 
which is our best chance to stem the global loss of biodiversity' (Burhenne-Guilmin and Glowka 1994). The expectations were high.

Nine years after the entry into force of the Convention, it is viewed with much more caution. Obviously, the CBD has so far not been able to halt, or even stem, the loss of ecosystems and species. A recent red data book, for example, revealed that 1,186 bird species are globally threatened (BirdLife International 2000), a slight increase from the 1,111 species listed in 1994 (Collar et al. 1994). Recent estimates of the rate of forest loss have failed to indicate a substantial slowing in the 1990s, and in 1997 and 1998, man-made forest fires destroyed large tracts of forest in Indonesia, Brazil and other countries (Matthews et al. 2000). Coral reefs are suffering dramatically, especially from coral bleaching events driven by climate change, the latest of which occurred in 1998, and from physical damage. By 1992, an estimated 10\% of the world's coral reefs had been lost; in 2000, this figure had risen to $27 \%$ (CBD document UNEP/CBD/SBSTTA/6/4, 19 December 2000; Secretariat of the Convention on Biological Diversity 2001).

Some commentators believe they have discovered the 'flawed foundation' of the Convention (Guruswamy 1999), since, while recognizing the conservation of biodiversity as a common concern of humankind, it leaves sovereignty over biological resources with individual states. Others view the $\mathrm{CBD}$ as strengthening existing North-South inequities through not effectively restricting the access for the North to biological resources of the South (Brand 2000).

However, as the CBD is still a young global treaty, it might be too early to assess its effectiveness, and there are certainly many signs which give hope for the Convention to become a strong force in saving the world's biodiversity. The aim of my paper is to demonstrate this and to show how ornithologists can contribute to CBD implementation and in doing so, to look at the opportunities and limitations the Convention offers for bird conservation.

\section{What is in the Convention for bird conservation?}

In order to understand the Convention, it is important to know that it is much more than a conservation treaty. It has three objectives: the conservation of biodiversity; the sustainable use of its components; and the fair and equitable sharing of the benefits arising out of the use of genetic resources (article 1). Thus, the CBD sets the conservation of the diversity of ecosystems, species and genes in the context of sustainable development.

The CBD covers a wide array of issues connected with biological diversity. This includes protected areas, restoration of ecosystems, invasive alien species, traditional knowledge of indigenous and local communities, ex situ conservation, incentive measures, research, training, public education, impact assessment, access to genetic resources, biotechnology and financial resources. The burden of implementation lies primarily with those states that have become a party to the Convention. By January 2002, 181 countries and the European Community had done so by ratifying the $\mathrm{CBD}$, showing the wide acceptance of the Convention. Countries have to report to the Conference of the Parties on measures they have taken for the implementation of the Convention, but there are no established indicators to measure the success of national action.

Unlike the Convention on International Trade in Endangered Species of Wild 
Fauna and Flora (CITES) or the Bonn Convention on Migratory Species (CMS), the CBD does not have lists of species that the parties have to protect. It does not ask parties to notify to its secretariat a list of priority areas as the Ramsar Convention on Wetlands does with the list of Wetlands of International Importance. The provisions on species protection and protected areas are rather vague: Parties shall, amongst others, 'establish a system of protected areas or areas where special measures need to be taken to conserve biological diversity ... promote the protection of ecosystems, natural habitats and the maintenance of viable populations of species in natural surroundings ... develop or maintain necessary legislation and/or other regulatory provisions for the protection of threatened species and populations' (article 8).

Of specific interest for bird conservation is article 7 , which requests parties to 'identify components of biological diversity important for its conservation and sustainable use' and refers specifically to 'ecosystems and habitats: containing high diversity, large numbers of endemic or threatened species ... required by migratory species' (annex I).

Arguably the most important provision of the Convention is article 6. It requires parties to '(a) develop national strategies, plans or programmes for the conservation and sustainable use of biological diversity ... (b) integrate, as far as possible and as appropriate, the conservation and sustainable use of biological diversity into relevant sectoral or cross-sectoral plans, programmes and policies'.

\section{National Biodiversity Strategies and Action Plans}

So far, an estimated 70 countries have completed their National Biodiversity Strategy and Action Plan (NBSAP), and many others are in the process of doing so. Interestingly, through the financial support of the Global Environment Facility (GEF, see below), a majority of developing countries have been able to develop and adopt their NBSAP, while some major developed countries have so far failed to do so. Many NBSAPs contain clear provisions on implementing the most challenging article $6 \mathrm{~b}$ (see above), such as establishing legislation on environmental impact assessment for road building, mining, gas and oil exploration. Targets are set for taking biodiversity into account within forestry, agriculture and fisheries. The Action Plans - which in some countries are separate documents from the Biodiversity Strategies - in many cases identify leading agencies and other institutional responsibilities, costs, funding sources, time frames and indicators of success (see also Fauna \& Flora International undated, Hagen undated, Prescott et al. 2000).

Information on birds has been used in the NBSAPs in a variety of ways. Many documents refer to the number of bird species in the respective country, but only a few include further details such as existing bird monitoring programmes and bird species action plans. The following examples highlight some of these approaches.

In the UK, a national Biodiversity Action Plan was adopted as early as 1994 . In the follow-up to this, 391 Species Action Plans, 26 of them for birds, and 45 Habitat Action Plans were developed, outlining leading agencies, outputs, time frames and costs. This government-led process was supported by a coalition of non-governmental organizations (NGOs), exemplifying the opportunities the 
CBD is offering for participation of civil society. A recent study by these organizations examined the success of 14 habitat and 59 Species Action Plans in the UK (Avery et al. 2001). While there is insufficient information on the status of eight habitats, only one was found to be in decline, but five showed signs of recovery. For the species, the picture is more even: for 17 species, there is insufficient information, 17 show signs of recovery, 11 are declining, one is lost, and 13 show no change.

Additionally, local governments all over the UK have established a local biodiversity action plan (LBAP) process, bringing local government, conservation organizations, foresters, farmers and business together. The LBAPs identify their own local conservation priorities within the framework of the national action plan. This is an exciting process, with local stakeholders taking up responsibility for implementing the CBD and with plenty of focus on birds and their habitats. Similar participatory approaches to implementation have begun in some other countries, such as India and Australia.

Within a related document, the UK Strategy for Sustainable Development uses population trends for wild birds as one of 15 headline indicators for sustainable development (DETR 1999). The document shows the decline of farmland birds and, to a lesser extent, of woodland birds from 1970 to 1998, based on data from a long-term monitoring programme, the Common Birds Census coordinated by the British Trust for Ornithology (BTO) and the Royal Society for the Protection of Birds (RSPB). The strategy sets the objective of reversing the long-term decline in populations of farmland and woodland birds.

The Canadian Biodiversity Strategy stresses the importance of monitoring programmes for the implementation of the CBD (Environment Canada 1995). Under the strategic direction 'Through research, increase our understanding of the status, genetic diversity and ecological relationships of species and populations to improve ecological planning and management', one of the proposed actions is 'monitoring forest bird populations and habitat associations through the Breeding Birds Survey, the Forest Bird Monitoring Program and other surveys outlined in the Canadian Landbird Monitoring Strategy' (Environment Canada 1998). This latter strategy is part of the activities of the Canadian Partners in Flight initiative, a joint project by government and NGOs that has also produced a Framework for Landbird Conservation in Canada.

The Seychelles Biodiversity Strategy and Action Plan gives an overview of the bird species of the Seychelles and develops a number of project proposals, including establishing action plans for the globally threatened endemic land birds such as Seychelles Scops-owl Otus insularis and Seychelles White-eye Zosterops modestus (Republic of Seychelles 1997). Subsequently, the Avian Ecosystem Restoration Project, funded by the Global Environment Facility (GEF)/World Bank and carried out by BirdLife Seychelles, is undertaking research and conservation activities for these species.

On a regional level, an interesting example for bird conservation policy is provided by the action plans for 23 globally threatened bird species in Europe (Heredia et al. 1996). Funded by the European Commission's LIFE programme and the RSPB, a consortium of NGOs, coordinated by BirdLife International and Wetlands International compiled action plans, which were subsequently adopted and published by the Council of Europe. This collaboration between government 
and NGOs makes a strong case for European governments to implement the action plans and to integrate them into their NBSAPs. The action plans should also be seen in the light of the Pan-European Biological and Landscape Diversity Strategy (PEBLDS), a regional mechanism for implementing the CBD. PEBLDS's action theme 11, action for threatened species, requests the development of 'species action plans for all species and their genetic diversity being threatened at the Pan-European level' (Council of Europe, UNEP and ECNC 1996).

\section{Funding for biodiversity}

Another way of learning about the national implementation of the CBD and the role of bird conservation is to look at projects that its financial mechanism is funding. The GEF, established in 1991, is a joint programme of the United Nations Development Programme (UNDP), the United Nations Environment Programme (UNEP) and the World Bank. It serves as the institutional structure operating the financial mechanism of the $\mathrm{CBD}$ and follows the guidance of the CBD's Conference of the Parties. By 2001, the GEF had allocated over US\$ 1.3 billion to 416 biodiversity projects, NBSAPs and national reports to the CBD in 136 countries, matched by US\$2.3 billion in co-financing (Secretariat of the Convention on Biological Diversity 2001). Many of these projects are relevant for bird conservation. An outstanding example is the joint project of BirdLife International Partner organizations in 1o African countries 'African NGO-Government Partnerships for Sustainable Biodiversity Action'. The project, which is supported by GEF/UNDP with US\$ 4.3 million, is built on the Important Bird Area (IBA) programme and tries to develop capacity for long-term biodiversity action at the sites identified as IBAs. In each of the participating countries National Liaison Committees have been established comprising representatives from the relevant government agency, UNDP, the BirdLife Partner organization, other relevant NGOs and the local communities at the sites. The objectives of the project are:

- to enhance biodiversity conservation by identifying, monitoring and advocating the protection of key sites (IBAs)

- to carry out necessary action to protect biodiversity at these IBAs

- to develop a cadre of national conservationists

- to create strong, financially sustainable partnerships and local constituencies

- to strengthen regional cooperation and coordination

- to extend the knowledge and experience gained from working in the 10 countries to other countries.

\section{Conclusions}

One might not share the criticism by Grajal and Stenquist (1998), who stated that 'the Global Environmental Facility (GEF) and other multilateral funding sources ... are pouring billions of conservation dollars into extremely data-poor decisions, whereas ornithologists have captured just a minimal amount of these funds'. But they make an important point when continuing that 'ornithological information is readily available and can provide timely answers to biodiversity 
action plans and conservation priorities'. Being the best-researched group of animals, birds indeed provide excellent indicators for many aspects of biodiversity, including the state of ecosystems and the success of efforts to conserve and sustainably use biological diversity (Bibby 1999). In many countries bird monitoring activities could, therefore, produce a first set of detailed data of distribution and trends in biodiversity and thus pave the way for adequate conservation measures. As the examples above show, some limited information on birds, including species richness, population trends, range changes and habitat requirements, has already found its way into framework documents relevant for landuse planning, such as NBSAPs. But there is still a long way to go. The task for holders of ornithological data is to turn their datasets into easily accessible and understandable information with clearly identified priorities for decision-makers, politicians, donors and, not least, the general public (Glowka et al. 1994).

At the national level, NBSAPs - the main mechanism for implementing the CBD - are increasingly becoming a significant framework for conservationrelated laws, regulations, funding decisions, projects and other activities. From the early experience provided by the NBSAPs, what birdwatchers and ornithologists can do to support the effectiveness of NBSAPs and other measures for implementing the CBD can be summarized as follows.

Bird surveys and monitoring activities should be planned in a manner that allows their results to be used in the decision-making process regarding planning for land use. Of specific importance are surveys of the following kind:

- Surveys that provide data on population trends of birds in specific habitats, such as agricultural, forest, grassland or freshwater habitats; in addition, though much more difficult to obtain, data should be collected on the productivity of bird populations in these habitats. Such information enables decision-makers to view the effects on biodiversity of agriculture, forestry or fisheries.

- Surveys that provide data on sites of significant importance for endemic, rare or threatened species, or those the habitats of which a country is legally obliged to protect, e.g. by international conventions such as the Convention on Migratory Species. BirdLife International's IBA programme is a good example for such an undertaking (Evans 1994, Heath and Evans 2000, Fishpool and Evans 2001). Land-use planning can take this information into account and damage to biodiversity from potential activities can be minimised.

The results of ornithological surveys should be produced in a format that can be easily understood by decision-makers. Graphs and user-friendly summaries are of particular importance.

Making bird surveys relevant for decision-making processes requires close collaboration between fieldworkers and conservation organizations. It is the latter who in most cases will be in a far better position than individual ornithologists to explore the opportunities for feeding the information from fieldwork into the political process. Regarding the CBD, in the course of recent years, many organizations such as the BirdLife Partners have gained the necessary understanding. Some crucial elements are:

- Acquiring an understanding of the national responsibilities and processes 
regarding the NBSAPs: what is the status of the NBSAP? Who is in charge within the government? Is there a national biodiversity committee leading on the NBSAP process? What are the opportunities for conservation organizations to get involved?

- In communication with decision-makers and the public, highlighting the value of information on birds for national and local land-use planning.

- Feeding relevant information on birds and their habitat requirements into the national NBSAP process.

- Working closely with ornithologists and other biodiversity scientists.

It is up to civil society to remind governments of the commitments they have made in acceding to the Convention. Birdwatchers, ornithologists and bird conservation organizations have their role to play here. Studying birds is a wonderful occupation, and we should do our best to make the results available for the implementation of global treaties like the Convention on Biological Diversity.

\section{Acknowledgements}

I am grateful to David Stroud (UK Joint Nature Conservation Committee), Colin Bibby, Nigel Collar, John Fanshawe and Julius Arinaitwe (BirdLife International) as well as John O'Sullivan and Dave Pritchard (Royal Society for the Protection of Birds) who provided very helpful comments on earlier drafts of this paper. Jeremy Speck (BirdLife International) helped with obtaining some of the references. The Royal Society for the Protection of Birds is kindly funding BirdLife International's Global Biodiversity Advocacy Programme of which this paper is a product.

\section{References}

The National Biodiversity Strategies and Action Plans referred to are accessible through the website of the Secretariat of the Convention on Biological Diversity (http:// www.biodiv.org).

Avery, M., Bourn, N., Davis, R., Everitt, J., Halahan, R., Harper, M., Parsons, M., Phillips, M., Sands, T., Williams, G. and Wynde, R. (2001) Biodiversity Counts: delivering a better quality of life. Biodiversity Challenge: Butterfly Conservation, Friends of the Earth, Plantlife, The RSPB, The Wildlife Trusts and WWF-UK.

Bibby, C. J. (1999) Making the most of birds as environmental indicators. In: Adams, N. J. and Slotow, R. H., eds. Proc. 22 Int. Ornithol. Congr., Durban. Ostrich 70: 81-88.

BirdLife International (2000) Threatened birds of the world. Barcelona: Lynx Edicions and Cambridge, U.K.: BirdLife International.

Brand, U. (2000) Planungssicherheit und Patente. Zur politischen ökonomie der biologischen Vielfalt. ILA 234: 4-7.

Burhenne-Guilmin, F. and Glowka, L. (1994) An Introduction to the Convention on Biological Diversity. Pp. 15-18 in A. F. Krattiger, J. A. McNeely, W. H. Lesser, K. R. Miller, Y. St. Hill and R. Senanayake, eds. Widening perspectives on biodiversity. Gland, Switzerland: IUCN and Geneva, Switzerland: International Academy of the Environment.

Collar, N. J., Crosby, M. J. and Stattersfield, A. J. (1994) Birds to watch 2. The world list of threatened birds. Cambridge, U.K.: BirdLife International. 
Council of Europe, UNEP and European Centre for Nature Conservation (1996) The PanEuropean Biological and Landscape Diversity Strategy. A vision for Europe's natural heritage. Strasbourg: Council of Europe, Geneva: UNEP and Tilburg: European Centre for Nature Conservation.

Department of the Environment, Transport and the Regions (1999) A better quality of life. A strategy for sustainable development for the United Kingdom. London: DETR.

Environment Canada (1995) Canadian Biodiversity Strategy: Canada's response to the Convention on Biological Diversity. Ottawa: Supply and Services.

Environment Canada (1998) Conserving wildlife diversity. Implementing the Canadian Biodiversity Strategy. Ottawa: Supply and Services.

Evans, M. I. (1994) Important Bird Areas in the Middle East. Cambridge, U.K.: BirdLife International.

Fauna \& Flora International (no date) National Biodiversity Strategy and Action Planning. BSAP preparation materials. Cambridge, UK: Fauna \& Flora International.

Fishpool, L. D. C. and Evans, M. I., eds. (2001) Important Bird Areas in Africa and associated islands: priority sites for conservation. Newbury, UK: Pisces Publications and Cambridge, U.K.: BirdLife International.

Glowka, L., Burhenne-Guilmin, F. and Synge, H. (1994) A guide to the Convention on Biological Diversity. Gland, Switzerland and Cambridge, U.K.: IUCN.

Grajal, A. and Stenquist, S. (1998) Research applications for bird conservation in the neotropics. Pp. 337-343 in J. M. Marzluff and R. Sallabanks, eds. Avian conservation. Research and management. Washington, D.C. and Covelo, CA: Island Press.

Guruswamy, L. D. (1999) The Convention on Biological Diversity: exposing the flawed foundations. Environ. Conserv. 26: 79-82.

Hagen, R. T. (no date) A guide for countries preparing National Biodiversity Strategies and Action Plans. New York: Biodiversity Planning Support Programme.

Heath, M. F. and Evans, M. I., eds. (2000) Important Bird Areas in Europe: priority sites for conservation, 2 vols. Cambridge, U.K.: BirdLife International.

Heredia, B., Rose, L. and Painter, M., eds. (1996) Globally threatened birds in Europe. Action plans. Strasbourg: Council of Europe.

Matthews, E., Payne, R., Rohweder, M. and Murray, S. (2000) Pilot analysis of global ecosystems: forest ecosystems. Washington, D.C.: World Resources Institute.

Prescott, J., Gauthier, B. and Nagahuedi Mbongu Sodi, J. (2000) Guide to developing a biodiversity strategy from a sustainable development perspective. Québec: Institut de l'énergie et de l'environnement de la Francophonie (IEPF), Ministère de l'Environnement du Québec, United Nations Development Programme (UNDP), United Nations Environment Programme (UNEP).

Republic of Seychelles (1997) Seychelles National Biodiversity Strategy and Action Plan. Mahé, Seychelles: Ministry of Environment, Ministry of Industry and Ministry of Foreign Affairs.

Secretariat of the Convention on Biological Diversity (2001) Global biodiversity outlook. Montreal: CBD, UNEP.

\section{PETER HERKENRATH}

BirdLife International, Wellbrook Court, Girton Road, Cambridge CB3 oNA, United Kingdom. E-mail: peter.herkenrath@birdlife.org.uk 